\title{
KANDUNGAN FITOKIMIA, KADAR TOTAL FENOL DAN AKTIVITAS ANTIOKSIDAN EKSTRAK RUMPUT LAUT Halymenia durvillae
}

\author{
Finka Widyastri Pontoh ${ }^{1}$, Grace Sanger ${ }^{2}$, Bertie E. Kaseger ${ }^{2}$, Djuhria Wonggo ${ }^{2}$, Roike I. \\ Montolalu $^{2}$, Lena J. Damongilala ${ }^{2}$, Daisy Makapedua ${ }^{2}$
}

${ }^{1}$ Mahasiswa pada Program Studi Teknologi Hasil Perikanan FPIK UNSRAT Manado.

${ }^{2}$ Staf Pengajar pada Program Studi Teknologi Hasil Perikanan FPIK UNSRAT Manado.

E-mail: pontohfinka@gmail.com

\begin{abstract}
Indonesian seaweed productions was 2017 recorded at 10.8 million tons. The export value of seaweed also grew by $3.09 \%$ per year. Efforts in Indonesian in processing raw materials into valuable products have not been maximally utilized so that seaweed commodities can be utilized by other countries. H. durvilae is classified as edible seaweed, containing bioactive compounds that are very beneficial for health, which can be used as a source of functional food that has biological activities such as antioxidants. Biactive compounds contained in seaweed such as: alkaloids, flavonoids, terpenoids, steroids, saponins, phenolics and antioxidant activity.

The purpose of this study was to determine the phytochemical content, total phenol content and antioxidant activity found in $H$. durvillae extracted using ethanol and etyl acetate solvents. Phytochemical test analysis included alkaloids, flavonoids, saponins, steroids and triterpenoids), total phenol levels using folin Ciocalteau and antioxidant activity tests using 1,1-diphenyl-2-picrylhydrazyl (DPPH).

The results of phytochemical content analysis showed that $H$. durvilae ethanol extract contained alkaloids with Wagner reagent, flavonoids with $\mathrm{H}_{2} \mathrm{SO}_{4}$ reagents, Saponins, triterpenoids and steroids while ethyl acetate extracts contained alkaloids with Wagner reagent and flavonoids with $\mathrm{H}_{2} \mathrm{SO}_{4}$ reagent, Total phenol content of $H$. durvillae ethanol extract $70 \%, 50 \%$ ethanol and etyl acetate 336,250 mg $\mathrm{GAE} / \mathrm{gr}$ respectively, $83,750 \mathrm{mg} \mathrm{GAE} / \mathrm{gr}$ and $86,250 \mathrm{mg} \mathrm{GAE} / \mathrm{gr}$, the antioxidant activity of the H.durvilae ethanol extract is greater than the ethyl acetate extract, with values in ethanol $70 \%$ of $465,163 \mathrm{ppm}$ and $50 \%$ ethanol is $614,796 \mathrm{ppm}$. The results of this study concluded that $H$. durvillae seaweed has a number of secondary metabolite compounds, total phenolic levels and activities of natural antioxidants so that they can be used as functional food ingredients for natural bioactive compounds.
\end{abstract}

Keyword: Halymenia durvillae, yield, phytochemicals, phenolic, antioxidant activity.

Produksi rumput laut di Indonesia pada tahun 2017 tercatat sebesar 10,8 Juta ton. Nilai ekspor rumput laut juga mengalami pertumbuhan sebesar 3,09\% per tahun. Upaya di Indonesia dalam mengolah bahan baku mentah menjadi produk bernilai guna belum dapat dimanfaatkan secara maksimal sehingga komoditas rumput laut dapat habis termanfaatkan oleh negara lain. H.durvilae tergolong edible seaweed, mengandung senyawa bioaktif yang sangat bermanfaat untuk kesehatan, yang dapat dimanfaatkan sebagai sumber pangan fungsional yang mempunyai aktivitas biologis seperti antioksidan. Senyawa bioaktif yang terkandung dalam rumput laut seperti: alkaloid, flavonoid, terpenoid, steroid, saponin, fenolik dan aktivitas antioksidan.

Tujuan penelitian ini dilakukan untuk mengetahui kandungan fitokimia, kadar total fenol dan aktivitas antioksidan yang terdapat pada H.durvillae yang diekstraksi menggunakan pelarut etanol dan etyl asetat. Analisa uji fitokimia meliputi alkaloid, flavonoid, saponin, steroid dan triterpenoid, kadar total fenol menggunakan folin Ciocalteau dan uji aktivitas antioksidan menggunakan 1,1-diphenyl-2picrylhydrazyl (DPPH).

Hasil analisis kandungan fitokimia diperoleh bahwa ekstrak etanol $H$. durvilae mengandung alkaloid dengan pereaksi wagner, flavonoid fengan pereaksi $\mathrm{H}_{2} \mathrm{SO}_{4}$, Saponin, triterpenoid dan steroid sedangkan ekstrak etil asetat mengandung alkaloid dengan pereaksi wagner dan flavonoid dengan pereaksi $\mathrm{H}_{2} \mathrm{SO}_{4}$, Kadar total fenol $\mathrm{H}$. durvillae ekstrak etanol $70 \%$, etanol $50 \%$ dan etyl asetat masingmasing 336,250 mg GAE/gr, 83,750 mg GAE/gr dan 86,250 mg GAE/gr, Aktivitas antioksidan ekstrak etanol $H$. durvilae adalah lebih besar dari ekstrak etil asetat, dengan nilai pada etanol $70 \%$ sebesar $465,163 \mathrm{ppm}$ dan etanol 50\% adalah 614,796 ppm. Hasil penelitian ini disimpulkan bahwa rumput laut $H$. durvillae memiliki sejumlah senyawa metabolit sekunder, kadar total fenolik dan aktivitas antioksidan alami sehingga dapat dimanfaatkan sebagai bahan pangan fungsional untuk sumber senyawa bioaktif alami.

Kata kunci: Halymenia durvillae, rendemen, fitokimia, kadar total fenol, aktivitas antioksidan. 


\section{PENDAHULUAN}

Rumput laut (seaweed) merupakan salah satu komoditas hasil perikanan yang memiliki potensi besar untuk dikembangkan di Indonesia (Desiana dan Hendrawati, 2015). Produksi rumput laut di Indonesia pada tahun 2017 tercatat sebesar 10,8 Juta ton. Nilai ekspor rumput laut juga mengalami pertumbuhan sebesar 3,09\% per tahun. Neraca perdagangan rumput laut Indonesia juga tercatat positif, dengan indeks spesialisasi produk (ISP) lebih tinggi dibanding negara-negara eksportir lainnya. Kondisi ini menandakan bahwa produk rumput laut memiliki daya saing kompetitif yang tinggi atau Indonesia merupakan negara eksportir rumput laut nomor 1 dunia khusus untuk jenis Eucheuma Cottoni dan Gracilaria, namun faktanya lebih dari $80 \%$ ekspor rumput laut kita masih didominasi oleh bahan baku kering (raw material) (KKP, 2018). Meskipun Indonesia memiliki pasokan rumput laut yang melimpah, namun hal tersebut tidak diimbangi dengan pemanfaatan sebagai produk industri yang signifikan. Upaya di Indonesia dalam mengolah bahan baku mentah menjadi produk bernilai guna belum dapat dimanfaatkan secara maksimal sehingga komoditas rumput laut dapat habis termanfaatkan oleh negara lain (Salam dan Larasati, 2014).

Rumput laut merupakan bagian terbesar dari tanaman laut. Rumput laut adalah tanaman tingkat rendah yang tidak memiliki perbedaan susunan kerangka seperti akar, batang dan daun yang sejati dan lebih dikenal dengan nama tumbuhan talus (Berhimpon, 2001). Kandungan utama rumput laut segar adalah air yang mencapai $80-90 \%$, sedangkan kadar protein dan lemaknya sangat kecil. Walaupun kadar lemak rumput laut sangat rendah, susunan asam lemaknya sangat penting bagi kesehatan (Winarno, 1990). Beberapa jenis rumput laut merupakan sumber potensial pangan fungsional yang dapat dimanfaatkan untuk kesehatan karena mengandung senyawa fitokimia (Lantah et.al., 2017; Soamole et.al., 2018) yang mempunyai akivitas biologis (zat bioaktif) yang diantaranya dapat bermanfaat sebagai antioksidan (Sanger et.al., 2013; Damongilala et.al. ,2013; Podungge et.al., 2018) dan antibakteri (Dotulong et.al.,2013).

Antioksidan yang terkandung pada rumput laut dapat melawan radikal bebas dalam tubuh, dimana radikal bebas adalah suatu molekul yang pada orbit terluarnya mempunyai satu atau lebih elektron yang tidak berpasangan, sifatnya sangat labil dan sangat reaktif sehingga dapat menimbulkan kerusakan pada tubuh manusia. Antioksidan sangat bermanfaat bagi kesehatan yaitu dapat mencegah antara lain pemicu penyakit degeneratif seperti: kanker, jantung, katarak, diabetes, hati, penuaan dini dan antioksidan juga dapat mempertahankan mutu produk pangan (Fithrani. D, 2009; Silalahi, 2002 dalam Djapiala et.al., 2013).

\section{METODOLOGI PENELITIAN}

\section{Bahan dan Alat \\ Bahan}

Bahan baku penelitian berupa $H$. durvillaea segar yang diambil di Pulau Nain, Kecamatan Wori, Kabupaten Minahasa, Provinsi Sulawesi Utara. Bahan-bahan berupa kantung plastik, kapas, aluminium foil, etanol $\left(96 \%, 70 \%\right.$ dan 50\%), etyl asetat $95 \%, \mathrm{H}_{2} \mathrm{SO}_{4}$, pereaksi dragendorff, pereaksi wegner, anhidrat asetat, $\mathrm{HCl} 2 \mathrm{~N}$, serbuk magnesium, akuades, 1,1-diphenyl-2-picrylhydrazil (DPPH), vitamin $\mathrm{C}, \mathrm{Mg}$, asam sulfat, reagen folin cioucalteu $50 \%$ dan $7 \% \mathrm{Na}_{2} \mathrm{Co}_{3}$.

\section{Alat}

Adapun alat yang digunakan antara lain: toples, timbangan, blender, erlenmeyer vakum, gelas ukur, labu ukur, spatula, labu takar, gelas beker, oven, vial, corong, kertas saring Whatman no. 42, neraca analitik, tabung reaksi, rak tabung reaksi, inkubator, pipet tetes, batang pengaduk, Spektrofotometer UV-VIS (Milton Roy 501).

\section{Metode Penelitian}

Penelitian ini dilaksanakan secara eksploratif deskriptif. Senyawa fitokimia yang dianalisis meliputi alkaloid, flavonoid, triterpenoid, steroid, dan saponin.

Data yang diperoleh dari hasil pengujian fenolik diolah dengan menggunakan persamaan regresi linier dari kurva standar asam galat. Data yang diperoleh dari aktivitas antioksidan setiap perlakuan berupa nilai absorbansi dan inhibisi yang kemudian diolah menggunakan persamaan regresi linier dari kurva standar $\mathrm{y}=\mathrm{ax}+\mathrm{b}$ untuk memperoleh nilai $\mathrm{IC}_{50}$.

\section{Prosedur Analisa Penelitian}

Analisis yang dilakukan pada rumput laut jenis $H$. durvillae dalam penelitian ini dibuat tiga kali perlakuan pada proses ekstraksi 
dengan menggunakan: Etanol 70\%, etanol $50 \%$ dan etyl asetat, yaitu uji rendemen, fitokimia (Flavonoid, Alkaloid, Saponin, Triterpenoid dan Steroid), kadar total fenol dan aktivitas antioksidan.

\section{Analisis Rendemen}

Rendemen diperoleh dari perbandingan berat ekstrak dengan berat sampel awal. Persentase rendemen dari sampel dapat dihitung dengan menggunakan rumus (AOAC, 1999 dalam Aristyanti 2017):

$$
\% \text { Rendemen }=\frac{\text { Bobot ekstrak }}{\text { Bobot sampel awal }} \times 100 \%
$$

\section{Analisis Fitokimia}

Analisis fitokimia merupakan analisis kualitatif yang dilakukan untuk mengetahui komponen bioaktif yang terkandung dalam tiap pelarut dari ekstrak H.durvillae. Analisis fitokimia yang dilakukan meliputi uji flavonoid, alkaloid, saponin, triterpenoid dan steroid (Harborne,1987 dalam Putranti, 2013).

Uji flavonoid:

a. Timbang sampel sebanyak 0,01 gram, ekstraksi dengan etanol sebanyak $5 \mathrm{ml}$ lalu disaring dengan kapas dan dipindahkan ke tabung lain (ekstrak etanol).

b. Pengujian menggunakan pereaksi $\mathrm{HCl}$ pekat, ekstrak etanol sampel ditambahkan $\mathrm{HCl}$ pekat sebanyak 2 tetes. Kocok kuat ekstrak tersebut lalu tambahkan $\mathrm{Mg}$ serbuk dan kocok kuat sekali lagi.

c. Sampel positif mengandung flavonoid dengan pereaksi $\mathrm{HCl}$ pekat apabila terdapat buih dengan intensitas yang banyak dan larutan berubah menjadi warna jingga.

d. Untuk pengujian menggunakan pereaksi $\mathrm{H}_{2} \mathrm{SO}_{4} 2 \mathrm{~N}$, ekstrak metanol sampel ditambahkan $\mathrm{H}_{2} \mathrm{SO}_{4} 2 \mathrm{~N}$ sebanyak 2 tetes lalu kocok kuat.

e. Sampel positif mengandung flavonoid dengan menggunakan pereaksi $\mathrm{H}_{2} \mathrm{SO}_{4}$ bila terdapat perubahan warna kuning, merah atau coklat yang sangat mencolok.

Uji alkaloid :

a. Timbang sampel sebanyak 0,01 gram, ekstraksi dengan kloroform amoniakal sebanyak $5 \mathrm{ml}$.

b. Saring dengan kapas dan pindahkan ke tabung A dan B.

c. Pada setiap tabung A dan B tambahkan pereaksi Dragendorf dan pereaksi Wagner.
- Pembuatan Pereaksi Dragendorf: sebanyak $8 \mathrm{~g} \mathrm{Kl}$ dilarutkan dalam $20 \mathrm{ml}$ akuades, sedangkan pada bagian lain dilarutkan $0,85 \mathrm{~g}$ bismut subnitrat dalam $10 \mathrm{ml}$ asam asetat glasial dan $40 \mathrm{ml}$ aquades. Kedua larutan ini dicampurkan. Larutan disimpan dalam botol yang berwarna coklat/gelap. Dalam penggunaannya, laruran ini diencerkan dengan $2 / 3$ bagian larutan $20 \mathrm{ml}$ asam asetat glasial dalam $100 \mathrm{ml}$ aquades.

- Pembuatan Pereaksi Wagner: sebanyak $1,27 \mathrm{~g}_{2}$ dan $2 \mathrm{~g} \mathrm{Kl}$ dilarutkan dalam $5 \mathrm{ml}$ akuades. Larutan ini kemudian diencerkan dengan akuades hingga $100 \mathrm{ml}$. Endapan yang terbentuk disaring dan disimpan dalam botol berwarna coklat/gelap.

d. Sampel pada tabung A positif mengandung alkaloid jika terdapat endapan berwarna kemerahan dan positif alkaloid pada tabung B jika terdapat endapan berwarna kecoklatan.

Uji Saponin :

a. Timbang sampel sebanyak 0,01 gram, ekstraksi dengan kloroform amoniakal sebanyak $5 \mathrm{ml}$. Saring dengan kapas dan pindahkan ke tabung lain.

b. Kocok kuat sampel tersebut dan diamkan selama 2 menit, kemudian tambahkan $\mathrm{HCl}$ $2 \mathrm{~N}$ sebanyak 2 tetes.

c. Kocok kuat lagi dan lihat apakah terbentuk buih setelah didiamkan selama 10 menit. Sampel positif mengandung saponin bila terdapat buih dengan intensitas yang banyak dan konsisten selama 10 menit.

Uji Triterpenoid dan Steroid :

a. Timbang sampel sebanyak 0,01 gram, ekstraksi dengan etanol sebanyak $5 \mathrm{ml}$. Saring menggunakan kapas lalu panaskan hingga kering.

b. Ekstraksi lagi dengan kloroform dan air (1:1). Ekstrak kloroform tersebut diteteskan pada plat tetes sebanyak 2 tetes dan biarkan sampai kering.

c. Tambahkan asam sulfat pekat sebanyak 1 tetes dan asam asetat anhidrat sebanyak 1 tetes.

d. Sampel positif mengandung triterpenoid apabila mengalami perubahan warna merah atau cokelat dan positif mengandung steroid apabila mengalami perubahan warna biru, ungu atau hijau.

\section{Uji Total Fenolik}

Ekstrak Rumput Laut $H$. durvillae sebanyak $10 \mathrm{mg}$ dilarutkan dalam $10 \mathrm{ml}$ 
akuades. Kemudian dipipet sampel sebanyak $0,5 \mathrm{ml}$ dan ditambahkan $0,3 \mathrm{ml}$ reagen FolinCioucalteu (Merk Milipore, Germany), $2 \mathrm{ml}$ $\mathrm{Na}_{2} \mathrm{CO}_{3}(7 \%)$ dan ditempatkan dengan akuades hingga volume larutan menjadi $5 \mathrm{ml}$. Selanjutnya, sampel divortex dan diinkubasi selama 2 jam, sampel diukur serapannya menggunakan spektrofotometer UV-VIS (Perkin Elmer Lambda 25) pada panjang gelombang $750 \mathrm{~nm}$.

\section{Uji Aktivitas Antioksidan}

Uji aktivitas antioksidan dengan metode DPPH sebagai berikut :

a. Untuk pembuatan larutan diphenylpicrylhydrazyl (DPPH) $4 \times 10^{-4} \mathrm{M}$, timbang $\mathrm{DPPH}$ sebanyak $1 \mathrm{mg}$ kemudian dimasukkan ke dalam vial $10 \mathrm{ml}$ dan tambahkan etanol sebanyak 6,26 ml kemudian diaduk hingga larut.

b. Tutup vial dengan rapat dan lapisi permukaan vial dengan alumunium foil (terhindar dari cahaya).

c. Siapkan larutan stock, dengan cara timbang sampel sebanyak 0,01 gram, masukkan ke dalam vial ukuran $10 \mathrm{ml}$.

d. Untuk mendapatkan larutan sampel 1000ppm, tambahkan sampel dengan etanol sebanyak 5 ml lalu diaduk sampai larut. Jika sampel sulit larut, gunakan vortex untuk memudahkan sampel larut.

e. Untuk pengujian sampel, masukkan berturutturut larutan stock dan etanol sesuai dengan volume. Pada masing-masing tabung reaksi tambahkan larutan DPPH sebanyak $1 \mathrm{ml}$ ke setiap tabung reaksi yang telah berisi larutan sampel dengan konsentrasi $200 \mathrm{ppm}(1 \mathrm{ml})$, $400 \mathrm{ppm}(2 \mathrm{ml}), 600 \mathrm{ppm}(3 \mathrm{ml})$ dan 800 ppm $(4 \mathrm{ml})$, tabung tersebut lalu biarkan selama 30 menit.

f. Selanjutnya diukur menggunakan spektrometer UV-Vis dengan panjang gelombang $517 \mathrm{~nm}$.

Kemampuan untuk meredam radikal bebas DPPH (inhibisi) dihitung dengan menggunakan persamaan:

Ket.:

$$
\% \mathrm{~h}=\frac{\mathrm{Ab}-\mathrm{As}}{\mathrm{Ab}} \times 100 \%
$$

$\% \mathrm{~h}: \%$ hambatan radikal bebas

$\mathrm{Ab}$ : Absorbansi blanko/absorbansi larutan DPPH (1,1diphenyl-2-phycrilhydrazil)

As : Absorbansi sampel

Nilai absorbansi dari setiap variasi konsentrasi dicatat dan dihitung nilai $\mathrm{IC}_{50}, \mathrm{IC}_{50}$ merupakan konsentrasi larutan substrat atau sampel yang mampu mereduksi aktivitas DPPH sebesar $50 \%$. Semakin kecil nilai IC $_{50}$ berarti semakin tinggi aktivitas antioksidan. Nilai konsentrasi penghambatan aktivitas radikal bebas sebanyak $50 \%\left(\mathrm{IC}_{50}\right)$ dihitung dengan minggunakan persamaan regresi yang diperoleh dari hubungan antara konsentrasi sampel dan presentase penghambatan aktivitas radikal bebas.

\section{HASIL DAN PEMBAHASAN}

\section{Rendemen Ekstrak}

Rendemen merupakan persentase bagian bahan baku yang dapat digunakan atau dimanfaatkan dengan total bahan baku. Rendemen rumput laut $H$. durvillae yang diekstrak dengan metode maserasi dapat dilihat pada tabel di bawah ini:

Tabel 1. Rendemen Ekstrak Kering H. durvillae.

\begin{tabular}{ccc}
\hline No. & Rendemen Ekstrak kering $\boldsymbol{H}$. durvillae \\
\hline 1. & Etanol 70\% & $3,16 \%$ \\
2. & Etanol $50 \%$ & $2,05 \%$ \\
3. & Etyl Asetat & $0,33 \%$ \\
\hline
\end{tabular}

\section{Senyawa Fitokimia}

Hasil analisa laboratorium, senyawa bioaktif yang terkandung dalam ekstrak rumput laut $H$. durvillae dapat dilihat pada tabel di bawah ini:

Tabel 2. Hasil Uji Ekstrak Kering H. durvillae.

\begin{tabular}{lcccc}
\multicolumn{1}{c}{$\begin{array}{c}\text { Metabolit } \\
\text { Sekunder }\end{array}$} & $\begin{array}{c}c \text { Hasil Uji Ekstrak } \\
\text { Etanol } \\
\text { Eo\% }\end{array}$ & $\begin{array}{c}\text { Etanol } \\
\mathbf{5 0 \%}\end{array}$ & $\begin{array}{c}\text { Etyl } \\
\text { Asetat }\end{array}$ & Warna \\
\hline Alkaloid: & & & & Coklat \\
a. Wagner & a. + & a. + & a. + & \\
b. Dragendorff & b. - & b. - & b. - & \\
Flavonoid : & & & & Kuning \\
a. $\mathrm{HCl}$ & a. - & a. & b. & \\
b. $\mathrm{H}_{2} \mathrm{SO}_{4}$ & a. + & b. + & c. + & \\
Saponin & $(+)$ & $(+)$ & $(-)$ & Berbusa \\
Triterpenoid & $(+)$ & $(+)$ & $(-)$ & Coklat \\
Steroid & $(+)$ & $(+)$ & $(-)$ & Coklat \\
\hline
\end{tabular}

Soamole, et.ai., (2018) melaporkan dalam hasil penelitiannya pada rumput laut jenis Gracilaria sp dalam pengujian senyawa bioaktif alkaloid dengan pereaksi Wagner $(+)$, alkaloid dengan pereaksi dragendorf $(+)$, saponin $(+)$, triterpenoid $(+)$, steroid $(+)$ dan flavonoid dengan pereaksi $\mathrm{Hcl}(+)$.

\section{Kadar Total Fenol}

Penetapan kandungan total fenol, langkah awal yang dilakukan adalah menimbang Asam Galat sebesar 0,01 gram dilarutkan dalam $10 \mathrm{ml}$ aquades, timbang $\mathrm{NaCO}_{3} 2$ sebesar 2 gram dilarutkan dalam 100 $\mathrm{ml}$ akuades dan timbang masing-masing sampel sebesar 0,01 gram dilarutkan dalam $10 \mathrm{ml}$ 
akuades. Setelah itu dibuat konsentrasi standar asam galat 10, 20, 40 dan $50 \mathrm{ppm}$.

Tabel 3. Kandungan total fenol pada rumput laut H. durvillae.

\begin{tabular}{llrrr}
\hline No. & Ekstrak Sampel & $\begin{array}{r}\text { Absorbansi } \\
\text { (Rata-rata) }\end{array}$ & $\begin{array}{r}\text { Ekuivalen } \\
\text { Asam Galat }\end{array}$ & $\begin{array}{c}\text { Kadar } \\
\text { Fenolik } \\
\text { mgGAE/g }\end{array}$ \\
\hline 1. & Etanol 70\% & 0,741 & 67,25 & 336,250 \\
2. & Etanol 50\% & 0,337 & 16,75 & 83,750 \\
3. & Etyl Asetat & 0,341 & 17,25 & 86,250 \\
\hline
\end{tabular}

Penelitian yang dilakukan oleh Sedjati (2018), pengukuran kadar total fenol ekstrak metanol Sargassum sp, hasil penelitiannya adalah 57,97 mg GAE/g. Sanger, et.al., (2018), melaporkan dalam penelitiannya ekstrak aseton Gracilaria salicornia mempunyai kadar total fenol 72,224 $\pm 6,01 \mu \mathrm{g} \mathrm{GAE} / \mathrm{g}$, dan berdasarkan penelitian Sanger, et.al., (2017) kadar total fenolik ekstrak etanol memiliki nilai $7.605 \mu \mathrm{g}$ $\mathrm{GAE} / \mathrm{g}$.

\section{Aktivitas Antioksidan}

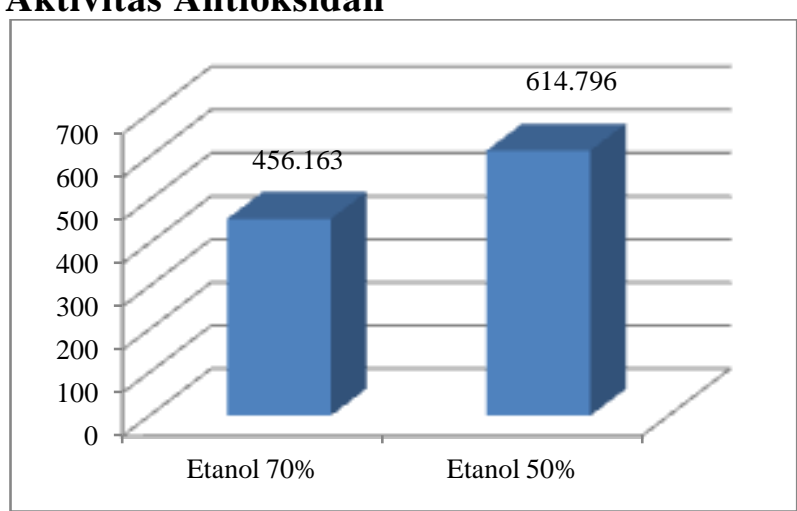

Gambar 1. Aktivitas antioksidan yang terdapat pada rumput laut $H$. durvillae.

Pada gambar di atas merupakan hasil pengukuran pada eksktrak etanol $70 \%$ dan $50 \%$, pada ekstrak etyl asetat tidak dapat dihitung $\mathrm{IC}_{50}$ nya. Sampel pembanding pada pengukuran aktivitas antioksidan pada penelitian ini adalah Vitamin C adalah sebesar 7,99 ppm (Lantah, 2017), maka aktivitas antioksidan pada rumput laut $H$. durvillae dikatakan sebagai antioksidan sangat lemah karena $>200$ ppm pada ekstrak etanol $50 \%$ dan $70 \%$.

Dalam penelitian yang dilakukan oleh Kasminah (2016), aktivitas antioksidan ekstrak rumput laut $H$. durvillae yang di ambil di Pantai Kutuh, Desa Kutuh, Kecamatan Kuta Selatan, Kabupaten Badung, Provinsi Bali, dengan menggunakan tiga jenis pelarut etanol, etyl asetat dan $\mathrm{N}$-heksan tergolong sangat lemah yaitu lebih dari 200 ppm.

\section{KESIMPULAN DAN SARAN}

\section{Kesimpulan}

Hasil penelitian dan pembahasan yang telah diuraikan, maka dapat diambil beberapa kesimpulan sebagai berikut:

1. Rendemen ekstrak rumput laut $H$. durvillae etanol $70 \%$ yang diperoleh $3,16 \%$, etanol $50 \%$ yaitu $2,05 \%$ dan ekstrak etyl asetat yang diperoleh adalah $0,33 \%$.

2. Kandungan fitokimia berupa alkaloid, flavonoid, saponin, triterpenoid dan steroid terdeteksi pada ekstrak rumput laut $H$. durvillae.

3. Kadar total fenol pada rumput laut $H$. durvillae ekstrak etanol $70 \%$, etanol $50 \%$ dan etyl asetat masing-masing $336,250 \mathrm{mg}$ GAE/gr, 83,750 mg GAE/gr dan 86,250 mg GAE/gr yang berarti rumput laut $H$. durvillae memiliki kandungan total fenol yang mampu berperan sebagai antioksidan alami.

4. Aktivitas antioksidan dengan metode DPPH pada rumput laut Halymenia durvillae sangat lemah dimana $\mathrm{IC}_{50}>200 \mathrm{ppm}$ yakni etanol 70\%: 465,163 ppm, etanol 50\%: 614,796 ppm yang membuktikan bahwa rumput laut ini memiliki aktivitas antioksidan yang sangat lemah namun dapat dimanfaatkan sebagai bahan pangan fungsional untuk pemenuhan peningkatan asupan gizi.

\section{Saran}

Perlu penelitian lanjut mengenai metode ekstraksi yang digunakan, untuk mendapat senyawa-senyawa bioaktif dan aktivitas senyawa lainnya dari rumput laut $H$. durvillae sehingga pengaplikasiannya terhadap bidang pangan dapat dimanfaatkan secara optimal.

\section{DAFTAR PUSTAKA}

Aristyanti, N. P. P., Wartini, N. M., Gunam, I. B. W. 2017. Rekayasa dan Karakteristik Ekstrak Pewarna Bunga Kenikir (Tagetes erecta L.) Pada Perlakuan Jenis Pelarut dan Lama Ekstraksi. Jurnal Rekayasa dan Manajemen Agroindustri. ISSN: 2503-488X, Vol.5, No.3 : (13-23).

Berhimpon, S. 2001. Industri pangan hasil perikanan bernilai tinggi (Valuable Commodities) salah satu unggulan agroindustri Sulawesi Utara. Makalah yang dipresentasikan pada seminar Perhimpunan Ahli Teknologi Pangan Indonesia (PATPI) Manado, 25 Januari 2001.

Damongilala, L., Widjanarko, S.B., Zubaidah, E., Runtuwene, M.R.J. 2013. Antioxidant Activity Against Methanol Extraction of Eucheuma cotoniiand Eucheuma. spinosum Collected From North Sulawesi Waters, Indonesia. Food Science and Quality 
Management. ISSN 2224-6088 (Paper) ISSN 22250557 (Online). Vol.17

Desiana, E dan T. Y. Hendrawati. 2015. Pembuatan Karaginan dari Eucheuma cottoni dengan Ekstraksi $\mathrm{KOH}$ menggunakan Variabel waktu Ekstraksi. Jurnal Fakultas Teknik Universitas Muhammadiyah Jakarta. $7: 1-7$

Djapiala, Y. F., Montolalu, L.A.D.Y., Mentang, F. 2013. Kandungan Total Fenol Dalam Rumput Laut Caulerpa racemosa Yang Berpotensi Sebagai Antioksidan. Jurnal Media Teknologi Hasil Perikanan Universitas Sam Ratulangi. Manado. Vol (1) No.2 Tahun 2013.

Dotulong, V., Montolalu L. A. D. Y., dan Damongilala L. J. 2016. Potensi Anti Bakteri Rumput Laut Merah Laurencia sp. Asal Perairan Sulawesi Utara. Jurnal, Bioteknologi Kelautan dan Perikanan.

Kasminah, 2016. Aktivitas Antioksidan Rumput Laut Halymenia durvillae dengan Pelarut Non Polar, Semi Polar dan Polar (Skripsi). Fakultas Perikanan dan Kelautan Universitas Airlangga. Surabaya.

Kementrian Kelautan dan Perikanan (KKP). 2018. Direktorat Jendral Perikanan Budaya. Artikel 3128 KKP : https://kkp.go.id/djpb/artikel/3128-kkp-pacupengembangan-daya-saing-rumput-laut-nasional. Diakses pada tanggal 19 Mei 2019.

Lantah, P. L. Montololu L. A. D. Y, dan Reo R. A. 2017. Kandungan Fitokimia Dan Aktivitas Antioksidan Ekstrak Metanol Rumput Laut KappaphycusAlvarezii. Jurnal Media Teknologi Hasil Perikanan,Vol. 5. No. 3.

Podungge A., Damongilala L. J., Mewengkang H. W. 2018. Kandungan Antioksidan Pada Rumput Laut Eucheuma Spinosum Yang Diekstrak Dengan Metanol Dan Etanol. Jurnal Media Teknologi Hasil Perikanan. Vol. 6, No. 1, Januari 2018.
Putranti. R. I. 2013. Skrining Fitokimia Dan Aktivitas Antioksidan Ekstrak Rumput Laut Sargassum duplicatum Dan Turbinaria ornata Dari Jepara. Tesis. Program Studi Magister Manajemen Sumberdaya Pantai. Fakultas Perikanan Dan Ilmu Kelautan. Universitas Diponegoro. Semarang.

Salam, M. R. B. dan D. Larasati. 2014. Pemanfaatan Material Rumput Laut melalui Ektraksi Karageenan untuk Desain Kemasan Edible. Jurnal Tingkat Sarjana Seni Rupa dan Desain. 1 (1) : 1-9.

Sanger, G. Widjanarko, S. B., Kusnadi, J. and Berhimpon S. 2013. Antioxidant Activity of Methanol Extract of Seaweeds Obtained From North Sulawesi. 2013. Food Science and Quality Management. Vol. 19. ISSN 2224-6088 (Paper).

Sanger, G. Rarung, K,L. Kaseger, E, B. Timbowo, S. (2017). Composition of Pigments and Antioxidant Activity in Edible Red Seaweed Halimenia durvilae Obtained from North Sulawesi. International Journal of ChemTech Research. Vol.10 No.15. pp 255-262.

Sanger, G. Kaseger, E, B. Rarung, K, L, Damongilala, L. (2018). Potensi Beberapa Jenis Rumput Laut Sebagai Bahan Pangan Fungsional, Sumber Pigmen dan Antioksidan Alami. Jurnal Pengolahan Hasil Perikanan Indonesia. 21(2): 208-218.

Sedjati, S. 2018. Kandungan Pigmen, Total Fenolik dan Aktivitas Antioksidan Sargassum sp. Jurnal Kelautan Tropis. Vol. 21. (2) : 137-144.

Soamole H., Sanger G., Harikedua S., Dotulong V., Mewengkang H., Montolalu R. 2018. Kandungan Fitokimia Ekstrak Etanol Rumput Laut Segar (Turbinaria sp., Gracilaria sp., dan Halimeda macroloba). Jurnal Media Teknologi Hasil Perikanan. Vol. 6, No. 3, Agustus 2018

Winarno F.G. 1990. Teknologi Pengolahan Rumput Laut. Jakarta. PT Gramedia Pustaka Utama. 